Teologia i Moralność, Volumen 13(2018), numer 2(24)

doi: 10.14746/tim.2018.24.2.11

ORCID: 0000-0002-7259-6152

MAREK CZACHOROWSKI

Kujawsko-Pomorska Szkoła Wyższa w Bydgoszczy

\title{
Pojęcie prawdy we wspólczesnej etyce prawniczej
}

Czy etyka może się obejść bez pojęcia prawdy? Cóż to jednak za „etyka” poza prawdą i fałszem? Cóż to za dobro - przedmiot etyki - poza prawdą i fałszem? Czy nie byłoby to dobro z konieczności odczłowieczające człowieka, istotę rozumną, czyli zdolną do odczytania prawdy o rzeczywistości?

Klasyczne rozumienie etyki uznaje ją za naukę ,kierowniczą” w stosunku do wszystkich tzw. praktycznych nauk (EN). Jakże bowiem uprawiać np. medycynę - zauważał już Galen - bez oparcia jej na wiedzy o istocie człowieka, czyli - koniec końców - wiedzy o tym, co jest dobre dla człowieka jako człowieka, a tym jest dobro moralne ${ }^{1}$. Bez wiedzy etycznej - wiedzy o ludzkim poziomie naszych czynów - medycyna zamiast leczenia człowieka na ludzkim poziomie staje się nieludzką medycyną.

Główną zasadą etyki klasycznej jest zatem zasada realizmu, domagająca się od człowieka uzgadniania swojego działania z niezależną od niego ontyczno-aksjologiczną rzeczywistością, czyli z odczytaną prawdą o tej rzeczywistości (por. Wojtyła 1986a [zwłaszcza rozdział: Zasada realizmu]). Dopiero

\footnotetext{
${ }^{1}$ Według Arystotelesa (i całej tradycji etyki klasycznej, do dzisiaj obecnej) „dzielność człowieka [czyli cnota moralna - M. Cz.] będzie trwałą dyspozycją, dzięki której człowiek staje się dobry i dzięki której spełniać będzie należycie właściwe sobie funkcje" (EN, II, 6, 1106 a). Cnota moralna jest zatem wyznaczona przez to, co należy do istoty człowieka. Tą swoistą dla człowieka funkcją jak Arystoteles wyjaśnia - jest „działanie duszy zgodne z rozumem lub nie bez rozumu” (EN, I, 7, 1098 a; por. Wojtyła 1969b, s. 233-234). Przypomina Wojtyła, że „dobrem moralnym jest to, przez co człowiek jako człowiek staje się i jest dobry, złem zaś moralnym to, przez co człowiek jako człowiek staje się i jest zły". Samo człowieczeństwo człowieka ,jest jedynym kluczem do zrozumienia tych wartości [moralnych - M. Cz.] i jedyną możliwą podstawą ich thumaczenia" (Wojtyła 1969b, s. 234; por. Wojtyła 1969a, s. 20; Aquinatis 1963, I-II, q. 56, art. 3). Wszystkie inne dobra - zwane pozamoralnymi - dotyczą dóbr ,peryferyjnych” wobec istoty człowieka, naszego człowieczeństwa. Można przecież być bogatym czy pięknym, ale złym człowiekiem.
} 
wtedy działanie jest na ludzkim poziomie, bo jest na poziomie istoty rozumnej i wolnej, istoty zdolnej - i zobowiązanej - do ujęcia prawdy.

Co więcej, to właśnie sądy etyczne (oceny i normy moralne) w sposób wyjątkowy pretendują do prawdziwości. Żądają bowiem one od nas - w sposób bezwarunkowy, niezależny od naszych chęci - rezygnacji z cenionych przez nas wartości, niekiedy i własnego życia. Jakże jednak je poświęcić (np. w obronie ojczyzny) czy zachować w największych pokusach wierność małżeńską, jeżeli nie mamy całkowitej pewności, że jest to nasz bezwarunkowy obowiązek? Czy jednak może być tego pewna istota rozumna, nie będąc przekonaną, że obligująca norma moralna jest prawdziwa, czyli zgodna z niezależną od nas rzeczywistością? Pytając o miejsce pojęcia prawdy we współczesności - zwanej nieraz ponowożytnością - nie można zatem nie postawić tego pytania wpierw współczesnej etyce ${ }^{2}$.

Odnotowujemy dzisiaj ogromne nią zainteresowanie. Na wyższych uczelniach prawie wszędzie jest ona wykładana, a w Polsce jest to zwłaszcza etyka medyczna, prawnicza i urzędnicza. Mnożą się też kodeksy etyczne rozmaitych profesji, a nawet SB stworzyło w latach 80. taki kodeks dla swoich pracowników, jakoby po to, aby „etycznie” wypełniali swoje obowiązki. Czy z tej obfitości należy się cieszyć? Czy rzeczywiście współczesny szeroki dostęp do etyki pomaga w poprawnym odróżnianiu dobra od zła moralnego, czynów na ludzkim poziomie i poniżej tego poziomu?

Trzeba to pytanie każdorazowo stawiać, ponieważ sytuacja metodologiczna etyki różni się od większości współczesnych nauk (np. biologii czy chemii), uprawianych tak samo lub w podobny sposób na całym świecie. Wbrew rozpowszechnionym mniemaniom $\mathrm{w}$ dziejach etyki mamy do czynienia z zerwaniem jej ciągłości (por. Wojtyła 1991, s. 25-26) 3 $^{3}$ i to wpierw wskutek dokonanej na progu nowożytności zmiany w koncepcji nauki (zob. Jaroszyński 2002). W wyniku tego mianem ,etyki” określa się współcześnie zupełnie róż-

2 Jak wygląda miejsce pojęcia prawdy na gruncie różnych koncepcji etyki, przedstawia K. Wojtyła, zwłaszcza Wojtyła 1958, s. 13-31, ale współcześni polscy etycy prawa zazwyczaj nie wykazują w swoich publikacjach śladów znajomości metaetycznego dorobku szkoły personalizmu lubelskiego (J. Woronieckiego, M.A. Krąpca, K. Wojtyły, T. Stycznia, A. Szostka).

3 Twierdzi tu autor, że nowożytna etyka ,znalazła się [...] w pozycji rozszczepienia [...] W sytuacji takiego rozszczepienia niemożliwa staje się etyka, pozostają tylko z jednej strony opisowe «nauki o moralności» [...], z drugiej zaś swoista «nauka moralności» (dedukcyjna logika norm)”; por. Wojtyła 1969a, s. 5-24 (twierdzi tu autor, że „etyka znajduje się na terenie myśli współczesnej w stanie swoistego zakwestionowania” - Wojtyła 1969a, s. 5). Por. Styczeń 1967 z. 2, s. 75-90. Ale już Kartezjusz twierdził, że etykę należy zbudować od początku, bo dotychczasowa pozbawiona jest fundamentów: „Pisma starożytnych pogan, traktujące o obyczajach porównywałem do pałaców bardzo pysznych i wspaniałych, ale zbudowanych jedynie na piasku i błocie; wynoszą bardzo wysoko cnoty [...], ale nie dosyć uczą je poznać, i często to, co nazywają tak pięknym imieniem, jest jedynie bezczułością lub pychą, lub rozpaczą, lub ojcobójstwem" (Descartes 1996; Część pierwsza). 
ne dyscypliny: o odmiennym przedmiocie, celu i metodzie. Różnią się one także stosunkiem do wspomnianej „zasady realizmu” - podstawowej zasady etyki klasycznej - czyli stosunkiem do wymagania prawdy w życiu moralnym.

Skupię się tu jednak tylko na współczesnej etyce prawniczej. Zawody prawnicze odgrywają dzisiaj ogromną rolę w życiu także politycznym, a od polityków oczekujemy wpierw pomocy w urządzeniu życia społecznego na ludzkim poziomie. Czy zatem wykładana w Polsce etyka prawnicza każdorazowo pomaga w identyfikacji tego ludzkiego poziomu? Czy jest w niej miejsce na pojęcie prawdy? Moja analiza nie rości sobie ambicji kompletności, ale skupię uwagę tylko na kilku przykładach sposobów uprawiania w Polsce etyki prawniczej ${ }^{4}$.

\section{Etologia zamiast etyki?}

W etyce prawniczej spotykamy się czasami ze sprowadzaniem etyki do innej dyscypliny naukowej, którą poprawnie nazwać należy „etologią” (na temat tej różnicy zob.: Styczeń 1999, s. 7). Zdaniem niektórych prawoznawców, etyka to „wiedza o przyjętych standardach etycznych i kryteriach oceny przyjmowanych w środowisku” (Safjan 2005, s. 9) S $^{5}$ Tak pojęta „etyka” jest to zatem de facto etologia, czyli psychologia i socjologia moralności opisujące przekonania moralne żywione w społeczeństwie, a nie - niezależne od nich - dobro i zło moralne. W etologii nie chodzi o badanie prawdziwości przyjmowanych w społeczeństwie ocen i norm moralnych, ale ustala się ich społeczne funkcjonowanie i ewentualne przyczyny tego faktu.

To zastępowanie etyki etologią jest zwykle konsekwencją zajętego akognitywistycznego i subiektywistycznego stanowiska w sprawie ocen i norm moralnych, czyli założenia, że nie mogą być one ani prawdziwe, ani fałszywe (zob. na temat tego związku: Styczeń 1972, s. 77). Wtedy też etyka jako nauka o dobru i złu moralnym (przedmiocie ocen i norm moralnych) jest niemożliwa, ale usprawiedliwione są badania etologiczne, cenne także dla prawoznawców, bo pozwalają na określenie priorytetów aksjologicznych określonego społeczeństwa, zgodnie z którymi jakoby należy tworzyć prawo obowiązujące w państwie.

\footnotetext{
${ }^{4}$ Problem miejsca prawdy w pojmowaniu prawa jest przedmiotem zainteresowań także innych autorów (zob. Piechowiak 2008, s. 71-83).

${ }^{5}$ Inny polski prawnik twierdzi, że „dla społeczeństwa charakteryzującego się pluralizmem moralnym nie można zbudować systemu etyki ogólnej, który cechowałby się niesprzecznością, zupełnością i hierarchicznością norm. Nie oznacza to jednak całkowitego odrzucenia prób konstruowania systemów moralnych, powinny to być jednak systemy moralne dobrze określonych grup społecznych, połączonych pewnymi związkami formalnymi” - Zirk-Sadowski 1979, s. 21.
} 
I rzeczywiście niektórzy przedstawiciele polskiej „etyki prawniczej” i teorii prawa wykluczają prawdziwość i fałszywość podstawowych sądów etycznych (ocen i norm moralnych), a nawet jest to stanowisko przeważające w polskim prawoznawstwie ${ }^{6}$. Jeden $\mathrm{z}$ autorów podzielający ten subiektywizm etyczny rezerwuje „racjonalność” ocen i norm moralnych tylko do spełnienia trzech wymagań formalnych:

Po pierwsze, musi on [sąd - M. Cz.] zostać dostatecznie zrozumiale i precyzyjnie wyrażony (wymóg ścisłej artykulacji). Po drugie, nie jest racjonalny żaden sąd opierający się na przesłankach faktycznych, o których wiadomo, że są fałszywe (np. [...] współcześnie spotykana wiara, że nie powinno się zapalać papierosa od świecy, bo wskutek tego traci życie marynarz). Po trzecie, racjonalność danego sądu wymaga jego zgodności (spójności) z innymi uznawanymi przez daną osobę przekonaniami (postulat konsekwencji logicznej) (Pietrzykowski 2011, s. 41-42).

Mamy tutaj zatem przykład „etyki” prawniczej, ale kwestionującej możliwość naukowej refleksji na temat moralności, skoro podstawowe sądy etyczne są jakoby nierozstrzygalne (nieracjonalne). Zdaniem tego autora, jego pozycja (nazwana ,umiarkowaną wersją relatywizmu etycznego, w której racjonalnym sądom etycznym nie przysługuje wprawdzie walor «obiektywnej» prawdziwości lub fałszywości, ale mogą być one racjonalne lub irracjonalne" - Pietrzykowski 2011, s. 42) ma umożliwiać sensowne podejmowanie sporów etycznych, w tym także spór o aksjologiczną różnicę pomiędzy życiem Matki Teresy i Rudolfa Hössa (zob. Pietrzykowski 2011, s. 40).

Być może jednak jest jakoś sensowne samo spieranie się przy użyciu podanych trzech kryteriów racjonalności etycznej, czy życie Matki Teresy jest lepsze niż życie megazbrodniarza z Auschwitz, ale nie sposób tego sporu racjonalnie rozstrzygnąć, skoro pierwotne sądy etyczne (,generalne racje etyczne", ,intuicyjne aksjomaty każdego rozumowania i argumentacji moralnej”) - zdaniem T. Pietrzykowskiego - „nie posiadają wartości prawdy lub fałszu” (Pietrzykowski 2011, s. 43). Koniec końców wykluczone jest w tej etyce prawniczej uznanie nazistowskich zbrodni za zawsze i wszędzie moralnie złe!

$\mathrm{Z}$ jakich jednak powodów autor odrzuca pojęcie prawdy - stanowisko „realizmu etycznego” (por. Pietrzykowski 2011, s. 29-39) - w swojej „etyce" prawniczej? Dlaczego odrzuca się etykę przypisującą ocenom i normom etycznym walor prawdziwości i fałszywości?

U podstaw tego rozstrzygnięcia znajdujemy wpierw błędne odczytanie pozycji klasycznego obiektywizmu etycznego. Autor bowiem twierdzi, że jest

${ }^{6}$ Tak twierdzi też M. Piechowiak pod adresem współczesnego prawoznawstwa (zob. Piechowiak 2009, s. 76-78). Subiektywizm etyczny broniony jest między innymi w: Ziembiński 1988, s. 40n; Woleński 1998, s. 63; Kordela 2001, s. 11; por. Winczorek 2011. 
on „w dużej mierze bezpośrednią konsekwencją powszechnie podzielanych wierzeń religijnych. Dobrem jest to, co stanowi wolę Najwyższego Stwórcy. O tym zaś, co Bogu «się podoba», dowiadujemy się dzięki objawionym przez Niego przykazaniom, świętym księgom [...]” (Pietrzykowski 2011, s. 30). Wprawdzie i taką pozycję znajdujemy w dziejach etyki (zwaną deontonomizmem teonomicznym - zob. na ten temat: Styczeń 1980, s. 35-40), to jednak nie jest to stanowisko etyki klasycznej, przyjmującej istotny związek moralności i kondycji bytowej człowieka jako istoty rozumnej i wolnej. Natomiast w deontonomizmie teonomicznym dobro i zło moralne ustawia się poza prawdą i fałszem, a zatem poniżej poziomu człowieka jako istoty rozumnej. Życie moralne dobre pojęte jest tu jako wymuszanie na człowieku posłuszeństwa irracjonalnym, gwałcącym ludzki rozum rozkazom Boga. Klasyczna odmiana obiektywizmu etycznego natomiast przyjmuje, że treść moralnych obowiązków jest rozpoznawalna samym ludzkim rozumem, bez pomocy objawienia (co przecież widzimy w etyce np. Arystotelesa) ${ }^{7}$ i nie jest rezultatem irracjonalnych kaprysów Boga, ale jest uzasadniona strukturą ontyczno-aksjologiczną rzeczywistości, odczytywanej przez człowieka.

Jeśli jednak omawiany autor dostrzega inne wersje obiektywizmu etycznego (np. Platona czy Arystotelesa), to znów brakuje ich poprawnego przedstawienia. Niezależnie od wszelkich różnic ich stanowisk ${ }^{8}$ wspólnie traktują dobro moralne jako odpowiadające istocie (naturze) człowieka ${ }^{9}$. Poprawne odczytanie klasycznej tradycji etycznej jest warunkiem wstępnym jakiejkolwiek krytycznej z nią dyskusji, który to warunek nie zostaje tutaj spełniony.

Przeciwko stanowiskom obiektywistycznym wytacza Pietrzykowski nade wszystko argument sformułowany w epoce oświecenia przez Dawida Hume’a,

${ }^{7}$ Sam autor jednak zauważa, że obiektywiści etyczni nie muszą opierać się na założeniach religijnych. Por. Pietrzykowski 2011, s. 32, gdzie mowa o stanowisku H. Grocjusza, wedle którego moralne prawa, wynikające z ludzkiej natury, obowiązywałyby, „nawet gdyby dopuścić [...] że Bóg nie istnieje lub że nie troszczy się o sprawy ludzkie" (Grocjusz 1957, s. 53).

${ }^{8}$ Te różnice autor odnotowuje na s. 30-31. Obiektywizm etyczny Arystotelesa wyprowadza „Z powszechnej zasady celowości”, a Platona z jego koncepcji idei.

${ }^{9}$ Stanowiska obiektywistyczne Platona i Arystotelesa jednak z niejasnych powodów przeciwstawia tym, którzy ugruntowują dobro moralne w ludzkiej naturze (zob. Pietrzykowski 2011, s. 32). W tekście mamy wiele przykładów podobnych nieporozumień. I tak utylitaryzm (jako stanowisko w sprawie normy moralności) zaliczony zostaje do stanowisk obiektywistycznych, chociaż właśnie subiektywizuje dobro moralne, sprowadzając je do subiektywnej przyjemności, innego dobra niż moralne. Natomiast ,intuicjonizm etyczny” bezpodstawnie utożsamiony zostaje z teorią „zmysłu moralnego”, ,przejawiającego się w wewnętrznym głosie sumienia” (s. 34). Akurat Hume jest jednym z czołowych przedstawicieli teorii „zmysłu moralnego”, chociaż - jak autor tym razem trafnie zauważa - jest przeciwnikiem kognitywizmu etycznego. Również „antynaturalistyczna” pozycja H.G. Moore'a przedstawiona została jako antykognitywistyczna i antyobiektywistyczna (zob. Pietrzykowski 2011, s. 35). Powszechnie twierdzi coś wręcz przeciwnego, bo „intuicjonizm” Moore’a to właśnie wersja kognitywizmu. Zob. Styczeń 1984, s. 7-23 (zwłaszcza s. 17). 
nazywany dzisiaj „błędem naturalistycznym”, czyli błędem dedukcyjnego wyprowadzenia twierdzeń powinnościowych z twierdzeń o faktach (Pietrzykowski 2011, s. 34) ${ }^{10}$. Zdaniem Hume'a, zauważenie tego błędu ,podrywa wszelkie potoczne systemy moralności i że pozwoli nam zobaczyć, iż rozróżnienie występku i cnoty nie opiera się jedynie na stosunkach między rzeczami zewnętrznymi i że nie postrzega go rozum" (Hume 1963, s. 227) ${ }^{11}$. W literaturze metaetycznej zwraca się jednak uwagę, że trudność formalno-logiczna, na którą zwrócił uwagę Hume, nie dotyczy tych modeli etyki obiektywistycznej, które ugruntowują etykę (pierwotne sądy etyczne) na swoistym doświadczeniu moralnym, nie wyprowadzając jej more geometrico z twierdzeń antropologicznych czy metafizycznych (zob. Styczeń 1972, s. 196; 1984 s. 7n; por. Piechowiak 2003, s. 11-20 [zob. s. 14n]).

Nie widać zatem powodu, aby - na podstawie przedstawionych rozstrzygnięć - opowiedzieć się za jakąś wersją subiektywizmu etycznego ${ }^{12}$, czyli uznać moralność za dziedzinę poza prawdą i fałszem, a zatem dziedzinę, której poważne traktowanie (wypełnianie obowiązków moralnych) oznaczałoby odczłowieczanie istoty rozumnej.

\section{Negacja pojęcia godności człowieka}

Eliminacja pojęcia prawdy z etyki prawniczej dokonuje się także na poziomie szczegółowych zasad etycznych, włącznie z naczelną zasadą (konstytutywną normą moralności, ujmującą istotę moralnego dobra) personalizmu etycznego, czyli zasadą afirmacji godności osoby ${ }^{13}$.

Pojęcie godności człowieka ${ }^{14}$ wprawdzie weszło do prawa (jest obecne także w polskiej konstytucji, podobnie jak w wielu innych krajach, począw-

${ }^{10}$ Autor jednak waha się, czy tylko większość, czy też wszystkie stanowiska kognitywistyczne i obiektywistyczne popełniają „błąd naturalistyczny”, piętnowany przez Hume'a i Moore'a (zob. Pietrzykowski 2011, s. 35). Wielu teoretyków prawa bardzo poważnie traktuje ,gilotynę Hume'a”. Zrodziła ona nawet tzw. „nową teorię prawa naturalnego” (m.in.: Finnis 1980).

${ }^{11}$ Różnica pomiędzy stanowiskiem Hume'a i Moore'a przedstawiona została jako różnica dotycząca norm moralnych (Hume) i ocen moralnych (Moore), gdy tymczasem to nie jest ważne $\mathrm{z}$ racji istotnego związku norm i ocen moralnych.

${ }^{12}$ Nazwanego przez autora „umiarkowanym relatywizmem” (Pietrzykowski 2011, s. 40).

13 Taki model etyki wypracowano zwłaszcza w obrębie szkoły lubelskiego personalizmu etycznego. Zob. Styczeń 1980. Por. Wojtyła 1986b; Krąpiec 2003, t. 4, s. 15; Biesaga 2016, s. 219-235.

${ }^{14}$ Niektórzy współcześni etycy prawa twierdzą, że etyka Kanta daje możliwość ucieczki przed nihilizmem etycznym. Wielokrotnie tę tezę jednak słusznie kwestionowano. (Zob. Jędraszewski 2009, s. 23). Karol Wojtyła wprawdzie doceniał znaczenie Kanta w obronie personalizmu etycznego, ale podkreślał, że jest to personalizm pozbawiony odpowiedniego uzasadnienia, wykluczonego metodologicznymi założeniami przyjętymi przez Kanta. Zob. Wojtyła 1986c, s. 259. Por. Styczeń 1972, s. 103. 
szy od zakończenia II wojny światowej i powstania Powszechnej Deklaracji Praw Człowieka, gdzie to pojęcie jest obecne - por. Lis, Balicki [red.] 2012 ${ }^{15}$ ) i słownika prawniczego, jednak w niektórych podręcznikach etyki prawniczej i naukowych monografiach kwestionuje się jego sensowność (zob. Pietrzykowski 2014, s. 139-146). Jakoby ma ono zakorzenienie w religijnych (chrześcijańskich) przekonaniach jego użytkowników, a zatem nie jest do przyjęcia na gruncie tzw. naturalnych źródeł poznania, czyli doświadczenia i rozumu (niewspartego wiarą). Twierdzi się też, że „prawnicze eksplikacje pojęcia godności pełne są, jak mało kiedy, rozmaitych patetycznych deklaracji” (Pietrzykowski 2014, s. 140), mających „mglisty” charakter, budzących „uzasadnioną nieufność" (Pietrzykowski 2014, s. 141). Pomijając ową „górnolotną retorykę”, przyjmuje się, że postulat respektowania „godności człowieka” sprowadza się do ,postulatu traktowania każdej istoty ludzkiej jako wartości samej w sobie" (Pietrzykowski 2014, s. 142). Tyle tylko, że wyraża się wątpliwość odnośnie do normatywnego moralnie znaczenia tego postulatu, ponieważ jakoby nie wszyscy ludzie mają posiadać - lub posiadać w tym samym stopniu - specyficznie ludzkie cechy (czyli być „osobami moralnymi”), a nie są ich pozbawione niektóre zwierzęta ${ }^{16}$. Gdyby zatem godność człowieka stanowiła ,pochodną tego rodzaju faktycznych własności, jakimi na ogół cechują się istoty ludzkie, musiałaby przysługiwać niejako «proporcjonalnie» do stopnia ich posiadania zarówno poszczególnym ludziom, jak i przynajmniej niektórym zwierzętom" (Pietrzykowski 2014 s. 143).

Innymi słowy: przynależność biologiczna każdego człowieka do gatunku homo sapiens jeszcze nie oznacza bycia „osobą moralną”, czyli podmiotem moralnych uprawnień i zobowiązań (zob. Pietrzykowski 2011, s. 131 i 136) ${ }^{17}$. Przykładem takich istot ludzkich, które jednak nie są „osobami moralnymi”,

${ }^{15}$ Ta publikacja podejmuje zwłaszcza prawne aspekty tego pojęcia. Mamy tutaj między innymi teksty: T. Guz, O naturze wrodzonej godności człowieka; M. Zdyb, Godność człowieka w świetle art. 30 Konstytucji Rzeczpospolitej Polskiej; M. Woch, Wielopoziomowe i wielopłaszczyznowe ujęcie godności człowieka w orzecznictwie Trybunatu Konstytucyjnego; D. Tyrawa, Rzady prawa w funkcjonowaniu administracji publicznej a godność człowieka; A. Komadowska, Karnoprawna ochrona godności człowieka; P. Wiśniewski, Ochrona godności człowieka w prawie Unii Europejskiej przed i po wejściu w życie Traktatu Lizbońskiego. Zarys problematyki.

${ }_{16}$ Twierdzi T. Pietrzykowski, że „Z empirycznego punktu widzenia nie ulega jednak wątpliwości, że nie wszystkie istoty ludzkie w jednakowym stopniu cechują się takimi przymiotami [...]. W odniesieniu do wielu istot ludzkich - jak choćby noworodków, osób głęboko upośledzonych, ludzi znajdujących się w trwałym stanie wegetatywnym (nie mówiąc nawet o embrionach, którym także przydawany bywa przymiot godności) - trudno mówić o «autonomii woli», samoświadomości, zdolności do racjonalnego myślenia, komunikacji językowej etc. Jednocześnie przynajmniej niektóre zwierzęta cechują się takimi własnościami w stopniu takim samym lub większym niż przynajmniej niektórzy ludzie" (Pietrzykowski 2014, s. 143).

${ }^{17}$ Tutaj wyraźnie widać, że Pietrzykowski jednak akceptuje odróżnienie wprowadzone przez cytowaną przez niego M.A. Warren. 
jest według Pietrzykowskiego nasciturus, noworodek, czy upośledzony dorosły. Są to - jego zdaniem - niewątpliwie ludzie, ale jeszcze nie są to „osoby moralne". Pietrzykowski twierdzi, że nie mają własności specyficznie ludzkich, dzięki którym należy im się specyficzny sposób postępowania, inny niż ten, który obowiązuje nas w przypadku zwierząt czy roślin.

Jednak na podstawie właśnie doświadczenia nie sposób się zgodzić z tezą, że niektórzy ludzie nie mają jakichś specyficznie ludzkich cech (bo jakoby nie mają ,autonomii woli, samoświadomości, zdolności racjonalnego myślenia, komunikacji językowej”), a niektóre zwierzęta w cechy te są wyposażone. Wprawdzie także śpiący czy nieprzytomny człowiek aktualnie nie wyraża swoich istotnie ludzkich cech (np. swojej ,,autonomii” czy zdolności do „racjonalnego myślenia” lub „komunikacji językowej” ${ }^{18}$ ), to oczywiście nie wątpimy, że są to ludzie. Właśnie z tego samego powodu nie możemy wykluczyć istotnych dla człowieka cech w przypadku ludzkiego zarodka, noworodka czy upośledzonego dorosłego. $\mathrm{Z}$ jakichś powodów (w pierwszym przypadku z powodu specyficznego etapu rozwoju) brakuje tylko możliwości przejawienia się tych specyficznie ludzkich własności czy możliwości. Jednak tak jak jesteśmy przekonani, że po przebudzeniu się (ewentualnym dojściu do przytomności) dorosły człowiek jest w stanie nawiązać komunikację językową, tak też po upływie dłuższego czasu również dziecko zazwyczaj przemówi, chyba że znów oddziałają jakieś przeszkody w rozwoju.

Także twierdzenie, że niektóre zwierzęta mają jakieś ludzkie cechy, jest pozbawione odpowiednich podstaw doświadczalnych, bo analiza zachowania się zwierząt nie wykazuje działalności rozumu czy wolnej woli. Rozumność człowieka to wpierw zdolność dotarcia poznawczego do tego, co ogólne, konieczne i niezmienne, a tego nie wykazują zwierzęta (zob. Krąpiec 1996) ${ }^{19}$. Zwierzęta nie wykazują także możliwości samostanowienia (autonomii), a ich zachowanie to tylko przejaw instynktu.

Koniec końców pojęcie ,godności” uważa Pietrzykowski za zbędne (niepotrzebne jest „hipostazowanie tego pojęcia” - Pietrzykowski 2014, s. $146^{20}$ ),

${ }^{18}$ Już wyliczenie tych specyficznie ludzkich (osobowych) cech rodzi podejrzenia, że antropologia, którą posługuje się T. Pietrzykowski, różni się od tego, co zdążyła wypracować do tej pory klasyczna antropologia filozoficzna. Jeżeli za specyficzną dla człowieka zdolność uzna się - jak to ma miejsce w omawianej monografii i podręczniku etyki prawniczej - przeżywanie bólu i posiadanie świadomości (zob. Pietrzykowski 2011, s. 131 i 136), to konsekwentnie trzeba zatrzeć różnice pomiędzy człowiekiem i zwierzęciem, ponieważ także zwierzęta doznają bólu i mają zmysłową świadomość.

${ }^{19}$ Jednak to starożytne odkrycie filozofii greckiej jest dzisiaj - jak widzimy - przez niektórych zapomniane, jak to widzimy np. w tzw. animal studies.

${ }^{20}$ Zdaniem tego autora, współczesne pojęcie godności (,w największym stopniu inspirowane myślą Immanuela Kanta”) wyrasta z tradycji chrześcijańskiej i jest ,jej niejako zsekularyzowaną postacią" (Pietrzykowski 2014, s. 143). 
bo jakoby „nakaz respektowania [...] «godności ludzkiej» oznacza w istocie postulat liczenia się [...] z dobrem, interesami każdego człowieka" (Pietrzykowski 2014, s. 146). Jednak tego postulatu autor już nie uzasadnia, zgodnie zresztą z omówionymi już założeniami swojej subiektywistycznej etyki, wykluczającej „racjonalność etyczną” odnośnie do podstawowych zasad etycznych. Stąd też wyklucza on możliwość przekładu tego wymagania na jakieś ogólnie ważne treściowo określone normy moralne. „Liczenie się z interesami każdego człowieka” „dotyczy jednak raczej ogólnych, abstrakcyjnych deklaracji niż ich konkretnego kształtu i praktycznych konsekwencji" (Pietrzykowski 2014, s. 148). Wobec tego na płaszczyźnie szczegółowych sporów moralnych (w tym i odnośnie do aborcji i eutanazji) Pietrzykowski twierdzi, że nie ma podstaw do uznania życia człowieka za bezwarunkowo nienaruszalne (zob. Pietrzykowski 2011, s. 136) ${ }^{21}$. Za przyjęciem tej nienaruszalności („świętości życia”) mają się kryć religijne rozstrzygnięcia (zob. Pietrzykowski 2011, s. 135; por. s. 165-166), czyli nieobligujące osób niewierzących. Bezwarunkowy szacunek dla życia człowieka jako istoty szczególnie wartościowej - zawsze i wszędzie domagającej się nieinstrumentalnego traktowania - pozbawiony jest, jego zdaniem, odpowiednich podstaw, a w każdym razie „nie jest jednak ani jedynym możliwym, ani nawet bezspornym sposobem postrzegania relacji życia do wielu innych wartości, takich jak: wolność, niepodległość, sprawiedliwość, honor" (Pietrzykowski 2011, s. 136) 22. Wynika stąd, że autor wyklucza jakieś obiektywne, ogólnie ważne moralnie rozwiązanie kolizji wartości wchodzących tutaj w rachubę. Nie zauważa bowiem koniecznej obiektywnej relacji pomiędzy wartością życia a wszystkimi innymi (także wymienionymi) wartościami, bo życie jest dobrem fundamentalnym, podstawą istnienia wszystkich innych wartości. Wynika stąd zobowiązanie do bezwarunkowego, ogólnie ważnego szacunku wobec życia i jego niekolidowalność z żadną inną wartością (por. Styczeń 1981, s. 39-67) ${ }^{23}$.

Jeśli jednak autor nie usprawiedliwia każdego zabójstwa drugiego człowieka - a uważa, że życie ludzkie powinno być prawnie chronione, nawet

${ }^{21}$ Zdaniem autora, ,pogląd o bezwzględnym prymacie wartości życia ludzkiego z pewnością jest uprawnionym stanowiskiem aksjologicznym”, ale „nie jest jednak ani jedynym możliwym, ani nawet bezspornym" (Pietrzykowski 2011, s. 136).

${ }^{22}$ W kontekście zagadnienia eutanazji autor tak samo twierdzi: „Nieuchronnie wymuszane rzeczywistymi dylematami moralnymi porzucenie dumnej retoryki równej świętości każdego życia i zastąpienie jej racjonalną oceną jego możliwej do osiągnięcia jakości sprawia, że moralnie usprawiedliwione mogą być zarówno decyzje o zakończeniu życia pacjenta ze względu na jego stanowczą i przemyślaną wolę (opartą na jego własnej ocenie jakości pozostałego mu życia), jak i decyzje o zakończeniu życia pacjentów [...]” (Pietrzykowski 2011, s. 169).

${ }^{23}$ Trzeba też odróżnić - także pod względem moralnym - poświęcenie własnego życia (tylko dopuszczenia własnej śmierci dla jakiejś wysokiej wartości) od zabicia siebie (bezpośredniego zamachu na własne życie). 
w przypadku poważnie chorych niemowląt i dorosłych, chociaż nie są to, jego zdaniem, „osoby moralne” - to nie z racji założenia „świętości życia” (bezwarunkowego zakazu jego naruszania), ale z jakichś innych powodów. Na gruncie zakładanego przez autora subiektywizmu etycznego racją tą jest obowiązek respektowania przeważającej opinii publicznej ${ }^{24}$, która aktualnie nie respektuje np. każdego dzieciobójstwa i eutanazji chorych. Domyślać się jednak należy, że ewentualna zmiana społecznego etosu prowadziłaby do akceptacji tych praktyk w ,etyce prawniczej”, która akceptuje wymuszanie na istocie rozumnej ślepego posłuszeństwa przeważającym opiniom społecznym! Bohater moralności to - w tej etyce prawniczej - konformista!

Tak oto widzimy, że współczesna etyka prawnicza - przedmiot akademickich wykładów - nieraz programowo odrzuca ${ }^{25}$ pojęcie prawdy w dziedzinie życia moralnego, prawdy ludzkich ocen i norm moralnych. Wyklucza się ich zgodność lub niezgodność z jakąś niezależną od nas rzeczywistością dobra i zła moralnego. Ten subiektywizm etyczny ma swój przekład w tzw. pozytywistycznej koncepcji prawa wykluczającej wymaganie jego rozumności (najważniejsza z czterech cech prawa, według klasycznej koncepcji - por. Aquinatis 1963, I-II q. 90), czyli zgodności z obiektywną rzeczywistością. Nie jest tą rozumnością w żaden sposób zobowiązany prawodawca, który - w społeczeństwie demokratycznym - ma tylko dbać o zgodność z przeważającymi poglądami moralnymi. Ten nurt „etyki” prawniczej albo zatem lekceważy sobie tezę klasycznej antropologii, że człowiek jest istotą rozumną (czyli zdolną do poznania prawdy i zobowiązaną do jej strzeżenia, a zatem jest homo ethicus), albo też zakłada, że człowiek nie jest istotą rozumną, ale bytem redukującym się do świata przyrody.

${ }^{24}$ Widzimy tę pozycję na gruncie nowożytnego subiektywizmu etycznego. Niezależnie od jego odmian zgodnie postuluje się respektowanie nade wszystko opinii publicznej, co widzimy zarówno u Kartezjusza (w jego zasadach „,moralności tymczasowej” z Rozprawy o metodzie), jak i J. Locke'a, którym to tropem idzie także I. Kant w swojej zasadzie „uniwersalizacji” (zob. MacIntyre 1987, s. 255; por. Czachorowski 2009, s. 157-181).

25 Poza obrębem zainteresowania tej pracy pozostała jeszcze inna koncepcja rozumności etycznej, wpisująca się także w dzieje nowożytnej i współczesnej etyki. Rozumowi przypisuje się nieraz zdolność kreowania granicy pomiędzy dobrem i złem, a nie jej odczytywanie. Drogę tę wytyczył w nowożytności I. Kant. Zob. Styczeń, 1980, s. 40-44 (zwłaszcza s. 44 i przypis 38). 


\section{THE NOTION OF TRUTH IN CONTEMPORARY LEGAL ETHICS}

\section{Summary}

The article indicates the reasons why in ethics the concept of truth finds a key place. The moral good is the good of man as a human being, and therefore must correspond to his rationality as the ability to know the truth about reality. Some concepts of contemporary legal ethics explicitly or indirectly reject this model of ethics, turning to the position of ethical subjectivism and replacing ethics with ethology (the theory of human moral convictions).

Keywords: ethics; legal ethics; truth of good; human being; ethical subjectivism; descriptive science of morality

Słowa kluczowe: etyka; etyka prawnicza; prawda o dobru; człowiek; subiektywizm etyczny; opisowa teoria moralności (etologia)

\section{BIBLIOGRAFIA}

Arystoteles (2012), Etyka nikomachejska, I 1, thum. D. Gromska, Warszawa.

Biesaga T. (2016), Godność osoby ludzkiej jako źródło normy personalistycznej, w: Wokól antropologii Karola Wojtyty, red. A. Maryniarczyk i in., Lublin, s. 219-235.

Borucka-Arctowa M., Woleński J. (1998), Wstęp do prawoznawstwa, Kraków.

Czachorowski M. (2009), Spór o nierozerwalność matżeństwa, Lublin.

Descartes R. (1996), Rozprawa o metodzie, tłum. T. Boy-Żeleński, Warszawa.

Finnis J. (1980), Prawo naturalne i uprawnienia naturalne, thum. K. Lossman, Warszawa.

Grocjusz H. (1957), O prawie wojny i pokoju, tłum. R. Bierzanek, Warszawa.

Hume D. (1963), Traktat o naturze ludzkiej, tłum. C. Znamierowski, Warszawa.

Jaroszyński P. (2002), Nauka w kulturze, Radom.

Jędraszewski M. (2009), Oświecenie i konieczność nowej racjonalności, „Filozofia Chrześcijańska”, t. 6: Osoba i racjonalność, Poznań.

Kordela M. (2001), Zarys uzasadnień aksjologicznych w orzecznictwie Trybunatu Konstytucyjnego, Bydgoszcz-Poznań.

Krąpiec M.A. (1996), Psychologia racjonalna, Lublin.

Krąpiec M.A. (2003), Godność (dignitas hominis), w: Powszechna encyklopedia filozofii, t. 4, red. A. Maryniarczyk i in., Lublin.

Lis W., Balicki A. red. (2012), Normatywny wymiar godności człowieka, Lublin.

MacIntyre A. (1987), Krótka historia etyki: filozofia moralności od czasów Homera do XX wieku, thum. A. Chmielewski, Warszawa.

Piechowiak M. (2003), Czy prawo naturalne to zespót norm?; w: Ecclesiae in iustitia servire opuscula Thaddaeo Walachowicz piae memoriae dedicata Poznań, s. 11-20.

Piechowiak M. (2008), Can Human Rights be Real? Can Norms be True?, w: Norm and Truth, red. M. Piechowiak, Poznań, s. 71-83.

Piechowiak M. (2009), Elementy prawnonaturalne w stosowaniu konstytucji RP, „Przegląd Sejmowy" 5(94): Studia i Materiały, s. 71-90. 
Pietrzykowski T. (2011), Etyczne problemy prawa, Warszawa.

Pietrzykowski T. (2014), Ujarzmianie Lewiatana. Szkice o idei rządów prawa, Katowice.

Safjan M. (2005), Przedmowa, w: R. Tokarczuk, Etyka prawnicza, Warszawa.

Styczeń T. (1967), Tradycyjne $i$ współczesne ujęcia etyki, „Roczniki Filozoficzne” t. 15, z. 2, s. 75-90 .

Styczeń T. (1972), Problem możliwości etyki jako empirycznie uprawomocnionej i ogólnie ważnej teorii moralności, Lublin.

Styczeń T. (1980), Etyka niezależna?, Lublin.

Styczeń T. (1981), Problem ogólnej ważności norm etycznych w aspekcie epistemologiczno-metodologicznym z uwzględnieniem indukcyjnych nauk o człowieku, „Zeszyty Naukowe KUL” t. 24: z. 1, s. 39-67.

Styczeń T. (1984), Spór o naukowość etyki, w: T. Styczeń, $W$ drodze do etyki, Lublin, s. 7-23.

Styczeń T. (1999), ABC etyki, Lublin.

Aquinatis Th. (1963), Summa theologiae, cura et studio P. Caramello, Torino.

Winczorek J. (2011), Czy istnieje etyka prawnicza? Kilka uwag ze stanowiska socjologicznej teorii norm, w: Etyka prawnicza. Stanowiska i perspektywy 2, red. H. Izdebski, P. Skuczyński, Warszawa.

Wojtyła K. (1958), O kierowniczej lub stużebnej roli rozumu w etyce. Na tle poglądów Tomasza z Akwinu, Hume'a i Kanta, „Roczniki Filozoficzne KUL”t. 6 z. 2, s. 13-31.

Wojtyła K. (1969a), Problem doświadczenia w etyce, „Roczniki Filozoficzne KUL” t. 17, z. 2, s. $5-24$.

Wojtyła K. (1969b), Problem teorii moralności, w: W nurcie zagadnień posoborowych, red. B. Bejze, t. 3, Warszawa, s. 233-234.

Wojtyła K. (1986a), Elementarz etyczny, Lublin.

Wojtyła K. (1986b), Miłość i odpowiedzialność, Lublin.

Wojtyła K. (1986c), Wykłady lubelskie, Lublin.

Wojtyła K. (1991), Człowiek w polu odpowiedzialności, Rzym-Lublin.

Ziembiński Z. (1988), Uzasadnianie twierdzeń, ocen i norm w prawoznawstwie, Warszawa.

Zirk-Sadowski M. (1979), Postulat etyki bezkodeksowej a stosunek prawa do moralności, Zeszyty Naukowe Uniwersytetu Łódzkiego, nr 25.

Marek Czachorowski - doktor habilitowany w dziedzinie filozofii; prof. KPSW w Bydgoszczy; filozof, etyk. Główne obszary zainteresowań: etyka Karola Wojtyły; filozofia prawa; etyka prawnicza, etyka urzędnicza, etyka seksualna, neuroetyka. Magisterium (Człowiek w polu odpowiedzialności wedlug Romana Ingardena) i doktorat (Stanowisko Karola Wojtyty/Jana Pawła II w sporze o mitość jako kryterium moralnej oceny antykoncepcji) na Wydziale Filozofii KUL pod kierunkiem ks. prof. T. Stycznia SDS. Habilitacja na Wydziale Filozofii Uniwersytetu Kardynała Stefana Wyszyńskiego; 1986-2014 pracownik naukowo-dydaktyczny w Katedrze Etyki KUL; 1999-2018 pracownik naukowo-dydaktyczny na Wydziale Studiów nad Rodziną UKSW. Kilkaset publikacji naukowych i popularnonaukowych. Aktualnie profesor w Kujawsko-Pomorskiej Szkole Wyższej w Bydgoszczy.

Publikacje książkowe: Nowy imperializm, czyli o tzw. edukacji seksualnej (Warszawa 1995), Wiek rewolucji seksualnej (Warszawa 1999), Ku epoce rodziny (Warszawa 2000), Europytania. Unia Europejska a prawa czlowieka (Lublin 2003), Heterofobia? Homoseksualizm a greckie korzenie Europy (Tychy 2006), 
Spór o nierozerwalność matżeństwa. Analiza filozoficzna (Lublin 2009), Skrypt $z$ wybranych zagadnień z bioetyki i etyki seksualnej (Lublin 2012); Gendermania (Szczecinek 2013); Pietas. Spór o filozoficzne podstawy obowiązów wobec rodziców (Lublin 2014); Światowy spisek przeciwko życiu (Szczecinek 2015). Redaktor działu etyka Powszechnej encyklopedii filozofii (Lublin 2000-2009). 